\title{
Cloud attenuation studies of the six major climatic zones of Africa for Ka and V satellite system design
}

\author{
Temidayo Victor Omotosho ${ }^{1, \star}$, Jit Singh Mandeep ${ }^{2}$, Mardina Abdullah ${ }^{2}$ \\ ${ }^{1}$ Covenant University, Department of Physics, Ota, Ogun State, Nigeria \\ ${ }^{2}$ Universiti Kebangsaan Malaysia, Department of Electrical, Electronic and System Engineering, Bangi, Malaysia
}

\author{
Article history \\ Received April 22, 2013; accepted June 24, 2013. \\ Subject classification: \\ Cloud attenuation, Ka band, Satellite, V band, Climate.
}

\section{ABSTRACT}

Cloud cover statistics, cloud base and top height, cloud temperature, frequency of precipitation, freezing height, total cloud liquid water content (TCLWC) and cloud attenuation data have been obtained for the six major climatic zones of Africa. The present results reveal a strong positive correlation between the monthly distribution of low cloud cover, cloud top height, cloud temperature, and frequency of precipitation in the six zones. The cumulative distribution of the TCLWC derived from radiosonde measurement in each climatic zone shows a departure from the TCLWC recommended by the ITU Study Group 3 data, with an exceedance percentage difference of $32 \%$ to $90 \%$ occurring $0.01 \%$ to $10 \%$ of the time. The underestimation of the TCLWC is greatest in the tropical rain forest. A comparison of the cloud attenuation cumulative distribution in the Ka and $V$ bands reveals that the International Telecommunication Union - Region (ITU-R) is an intergovernmental organization that develops rain model based on collected data around the world. This model underestimates the cloud attenuation in all of the six climatic zones by $2.0 \mathrm{AB}$ and $4.7 \mathrm{AB}$ for the arid Sahara desert, $1.3 \mathrm{AB}$ and $3.0 \mathrm{~dB}$ in semi-arid North Africa, $1.3 \mathrm{~dB}$ and $1.5 \mathrm{~dB}$ in savannah North Africa, 2.0 $\mathrm{AB}$ and $3.6 \mathrm{AB}$ in the tropical rain forest, $1.3 \mathrm{~dB}$ and $2.9 \mathrm{~dB}$ in savannah South Africa and $0.9 \mathrm{~dB}$ and $2.6 \mathrm{~dB}$ in semi-arid South Africa, respectively, at 30 and $50 \mathrm{GHz}$. Overall, the cloud attenuation in the tropical rain-forest zone is very high because of the high annual total cloud cover (98\%), high annual frequency of precipitation (4.5), low annual clear sky amount (8\%), high cloud depth $(10,937 \mathrm{~m})$, high $0^{\circ} \mathrm{C}$ isotherm height $(4.7 \mathrm{~km})$, high TCLWC (4.0 kg/m2 at 0.01\%) and low seasonal cloud base height $(356 \mathrm{~m})$.

\section{Introduction}

Raincis considered to be most important attenuator for high-availability satellite links. Impairment caused by clouds is often ignored, but the frequent presence of clouds may cause persistent attenuation for low-margin modern systems operating in the $\mathrm{Ka}$ $(30 / 20 \mathrm{GHz})$ and $\mathrm{V}(50 / 40 \mathrm{GHz})$ bands [Omotosho et al. 2011]. Rain can be traced to the formation of clouds; therefore, for low-availability satellite services such as very small aperture terminals (VSAT) and ultra small aperture terminals (USAT), rain effects may only contribute a relatively small part of the total propagation link margin [Omotosho and Babtude 2010]. Deep fades may occur because of the higher probability of the occurrence of clouds [Salonen and Uppala 1991, Mattioli et al. 2009]. Many experimental studies have been conducted on millimeter wave atmospheric attenuation. Based on these studies, researchers can estimate with some confidence the losses arising from cloud attenuation up to approximately $200 \mathrm{GHz}$ [Slobin 1982, Salonen and Uppala 1991, Al-Ansari et al. 2003, Sarkar et al. 2005, Mandeep and Hassan 2008, Mattioli et al. 2009]. Some models that use several effective input parameters have been developed [Altshuler and Marr 1989, Dintelmann and Ortgies 1989, Dissanyake et al. 1997, Wrench et al. 1999, ITU-R 2009a].

Technological advances in remote sensing, the increasing number of satellite missions (including NASA (A-Train) Atmospheric Infrared Sounder (AIRS), Moderate Resolution Imaging Spectroradiometer (MODIS) key instrument aboard the Terra (EOS AM) and Aqua (EOS PM) satellites that collects complimentary observations of Earth's surface and atmosphere, Cloud Cover Statistical Analysis Program (CLOUDSAT) is an experimental satellite that will use radar to study clouds and precipitation from space, Cloud-Aerosol Lidar and Infrared Pathfinder Satellite Observations (CALIPSO) is a lidar that provides high-resolution vertical profiles of aerosols and clouds, Tropical Rain Measurement Mission (TRMM) Microwave Imager is a passive microwave sensor designed to provide quantitative rainfall information over a wide swath under the TRMM satellite, and the Cloud and Earth Radiation Sensor (CERES), direct measurements and recorded observations by weather sta- 


\begin{tabular}{|c|c|c|c|c|c|c|}
\hline $\begin{array}{c}\text { Climatic } \\
\text { zones }\end{array}$ & $\begin{array}{l}\text { Latitude } \\
\text { (degrees) }\end{array}$ & $\begin{array}{l}\text { Longitude } \\
\text { (degrees) }\end{array}$ & $\begin{array}{l}\text { Rainfall } \\
\text { type }\end{array}$ & $\begin{array}{l}\text { Climate } \\
\text { type }\end{array}$ & $\begin{array}{c}\text { Annual rainfall } \\
\text { accumulation }(\mathrm{mm})\end{array}$ & $\begin{array}{l}\text { Vegetation } \\
\text { type }\end{array}$ \\
\hline $\begin{array}{c}\text { (1) Arid Sahara } \\
\text { desert }\end{array}$ & $15-32.5 \mathrm{~N}$ & $11.5 \mathrm{~W}-32.5 \mathrm{E}$ & $\begin{array}{l}\text { Sparse } \\
\text { rainfall }\end{array}$ & $\begin{array}{l}\text { Desert uniformly dry, no } \\
\text { moisture, temperature is } \\
-4 \text { to } 54 \mathrm{C}\end{array}$ & less than $130 \mathrm{~mm}$ & few oases exist \\
\hline $\begin{array}{l}\text { (2) Semi arid } \\
\text { North Africa }\end{array}$ & $12-17.5 \mathrm{~N}$ & $11.5 \mathrm{~W}-32.5 \mathrm{E}$ & $\begin{array}{l}\text { Low } \\
\text { rainfall }\end{array}$ & Steppe climate & $\begin{array}{l}100 \text { to } 200 \mathrm{~mm} \\
\text { confine to June } \\
\text { and September }\end{array}$ & $\begin{array}{l}\text { relatively sparse } \\
\text { grass, shrubs pre- } \\
\text { dominate }\end{array}$ \\
\hline $\begin{array}{l}\text { (3) Savannah } \\
\text { North Africa }\end{array}$ & $7.5-12.5 \mathrm{~N}$ & $11.5 \mathrm{~W}-32.5 \mathrm{E}$ & $\begin{array}{l}\text { Moderate } \\
\text { rainfall }\end{array}$ & $\begin{array}{l}\text { Hot dry season (winter) } \\
\text { wet season (summer) } \\
\text { occupy one-fifth of } \\
\text { Africa land }\end{array}$ & 100 to $400 \mathrm{~mm}$ & $\begin{array}{l}\text { Vary vegetation } \\
\text { open canopied } \\
\text { forest, grassy } \\
\text { under story } \\
\text { dominate }\end{array}$ \\
\hline $\begin{array}{l}\text { (4) Tropic Rain } \\
\text { Forest }\end{array}$ & $7.5 \mathrm{~S}-7.5 \mathrm{~N}$ & $11.5 \mathrm{~W}-32.5 \mathrm{E}$ & $\begin{array}{l}\text { High-all-year } \\
\text { rainfall }\end{array}$ & $\begin{array}{l}\text { Wet and warm climate, } \\
\text { tropical wet, no month } \\
\text { is rainless }\end{array}$ & 1800 to $3000 \mathrm{~mm}$ & $\begin{array}{c}\text { Evergreen trees, } \\
\text { oil palms, tropi- } \\
\text { cal hard woods, } \\
\text { dense surface } \\
\text { shrubs and ferns } \\
\text { moses }\end{array}$ \\
\hline $\begin{array}{l}\text { (5) Savannah } \\
\text { South Africa }\end{array}$ & $17.5 S-7.5 S$ & $14-42.5 \mathrm{E}$ & $\begin{array}{l}\text { Moderate } \\
\text { rainfall }\end{array}$ & $\begin{array}{l}\text { Hot dry season (winter) } \\
\text { wet season (summer) oc- } \\
\text { cupy one-fifth of Africa } \\
\text { land }\end{array}$ & 100 to $400 \mathrm{~mm}$ & $\begin{array}{l}\text { Vary vegetation } \\
\text { open canopied } \\
\text { forest, grassy } \\
\text { under story } \\
\text { dominate }\end{array}$ \\
\hline $\begin{array}{l}\text { (6) Semi arid } \\
\text { South Africa }\end{array}$ & $22.5 S-17.5 S$ & $17-32.5 \mathrm{E}$ & $\begin{array}{l}\text { Low } \\
\text { rainfall }\end{array}$ & Steppe climate & 100 to $200 \mathrm{~mm}$ & $\begin{array}{l}\text { relatively sparse } \\
\text { grass, shrubs pre- } \\
\text { dominate }\end{array}$ \\
\hline
\end{tabular}

Table 1. Climate summary and geographical coordinates of the of the six climatic zones.

tions, and the NASA Student Cloud Observation Online (SCOOL) have contributed greatly to the wealth of cloud data available to the scientific community for indepth radio wave propagation studies. The most important properties of clouds for the cloud attenuation modeling of earth-space communication links in the $\mathrm{Ka}$ and $\mathrm{V}$ bands are the statistics of cloud cover, cloud base and top height, cloud thickness, total cloud liquid water content, cloud temperature, horizontal extent and variability. Cloud climatologies have recently been developed from two types of data: (1) radiance measured by satellites in geostationary and polar orbits and (2) visual observation of clouds from the Earth's surface, as coded in weather reports from stations on land and ships on the ocean. Satellites principally detect clouds using the visible and thermal-infrared wavelengths. During the day, clouds can be detected in both wavelength regions, but at night they can be detected only in the thermal infrared. Satellite observations of clouds are obtained more frequently than surface observations and cover more land and ocean area, but ground observation offers a useful adjunct to satellite observation. The surface observer views clouds from below; thus, they observe low clouds that are often hidden from the view of satel- lites by higher clouds. Multiple cloud layers often occur together; consequently, the views from above and below are complementary [Warren and Hahn 2003].

In this work, we report the annual clear sky cloud cover statistics, cloud base and top height, cloud temperature, and frequency of precipitation based on cloud climatology data from ground and satellite observations from 1952 to 2008. Additionally, we report the integrated cloud liquid water content $\left(\mathrm{kg} / \mathrm{m}^{2}\right) \mathrm{ob}-$ tained from daily radiosonde data measurements from 1953 to 2011 for the six major African climatic zones and compare it with the integrated cloud liquid water content data of the recent ITU-R study group 3 (SG3) [ITU-SG3 website]. The above data sets were used as input climatic data to investigate the impact of clouds on the $\mathrm{Ka}(30 \mathrm{GHz})$ and $\mathrm{V}(50 \mathrm{GHz})$ bands for the six major climatic zones of Africa (the arid Sahara desert, semi-arid North Africa, the North African savannah, the tropical rain forest, the South African savannah and semi-arid South Africa. Table 1 presents the geographical coordinates and the climate summary for the six zones, including the rainfall type, annual rainfall accumulation, annual temperature, and vegetation type. Figure 1 presents the map of Africa and the boundary 
of each climate zone [Adeyewa and Nakamura 2003]. Finally, out of eight cloud attenuation models available in the literature, the two best estimates of cloud attenuation based on recent experimental data were used to estimate cloud attenuation, and the two results are compared for the African climatic zones.

\section{Cloud and radiosonde data sources}

Cloud-cover data were collected for six major African climatic zones, and the average properties of the different cloud types from daily visual observations of cloud climatology at land stations worldwide between 1952 and 1996, developed by Hahn [Hahn and Warren 1999], were used for their analysis. Cloud-cover percentages were determined for different cloud types over land areas with a resolution of $5^{\circ} \times 5^{\circ}$ in longitude and latitude. The data grid resolution is commensurate with the geographical distribution of the data collection centers, and this level of resolution is deemed reasonable for the calculation of cloud attenuation in the six major climate zones of Africa. Five cloud types were selected in this work for the study of cloud-cover statistics: stratus $(S t)$, stratocumulus $(S c)$, cumulus $(C u)$, cumulonimbus $(\mathrm{Cb})$ and nimbostratus $(\mathrm{Ns})$. The seasonal cloud base height data from 1970 to 1996 were obtained from Hahn [Hahn and Warren 1999]. The mean cloud temperature and cloud top height were obtained from the International Satellite Cloud Climatology Project (ISCCP, 1983-2008) and the Cloud-Aerosol Lidar and Infrared Pathfinder Satellite Observations (CALIPSO, 2006-2011) data, respectively, for the six climate zones. The retrieved cloud data were processed and averaged on monthly, annual, and seasonal bases.

Radiosonde data were retrieved from the integrated global radiosonde archive (IGRA) [Durre et al. 2006] from 1953 to 2011. Six stations were chosen to represent each climatic zone: Sebha, Libya, representing the arid Sahara desert; Bamako-Senou, Mali, representing semi-arid North Africa; Bouake, Côte d'Ivoire, representing the North African savannah; Lagos Oshodi, Nigeria, representing the tropical rain forest; Nampula, Mozambique representing the South African savannah; and Bulawayo, Zimbabwe, representing semi-arid South Africa. Table 2 presents detailed information about the six stations used in this study. Consistent radiosonde (Sonde Model I1 VAISALA RS80) measurements, obtained twice daily at 00 and 12 GMT from 1953 to 2011, contain data for pressure, temperature, relative humidity, and dew point temperature at different heights as well as $0^{\circ} \mathrm{C}$ isothermal height (freezing height) with a resolution varying from a few tens of meters to a few hundreds of meters to a height of $37 \mathrm{~km}$. The best daily radiosonde data were selected

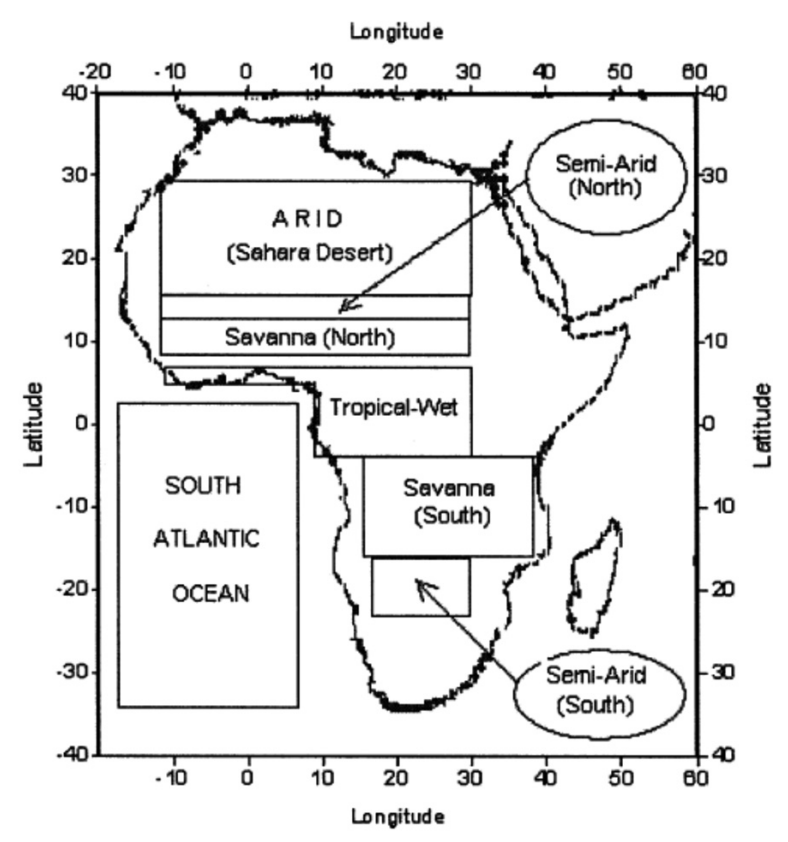

Figure 1. Major Climatic zones of Africa used in this study. Their geographical coordinates are specified in Table 1.

for each station and used in this work, covering approximately 124 to 15,396 radiosonde launches. These data were used to estimate the cloud liquid water statistics for each of the six stations. The radiosonde data can indicate the presence of cloud liquid water if the relative humidity exceeds the critical humidity, as defined by [Geleyn 1980]. The phase of the water within the cloud is determined by the temperature. If the temperature is greater than $0^{\circ} \mathrm{C}$, the water is completely in the liquid phase; if the temperature is less than $-20^{\circ} \mathrm{C}$, only ice exists. The range of temperatures between $0^{\circ} \mathrm{C}$ and $-20^{\circ} \mathrm{C}$ yields a mixture of liquid water and ice. Salonen [Salonen and Uppala 1991] proposed a model for cloud water density in terms of the temperature and height from the cloud base that can be used to obtain the liquid water density profile within a cloud. The water density within a cloud can vary significantly. Pure ice does not cause the attenuation of radio signals, but super-cooled water can cause significant attenuation [Animesh and Chakraborty 2009].

\section{Theoretical considerations}

Several models are available in the literature for the prediction of cloud attenuation [Gunn and East 1954, Staelin 1966, Slobin 1982, Altshuler and Marr 1989, Liebe 1989, Salonen and Uppala 1991, Dissanyake et al. 1997, ITU-R 2009a]. The Salonen and Uppala and ITU-R models have been reported to produce the best estimates of cloud attenuation, based on experimental data in the equatorial and tropical climates [Mandeep and Hassan 2008]. These models are particularly effective because the cloud attenuation component is obtained from the liquid water content, which is calculated 
OMOTOSHO ET AL.

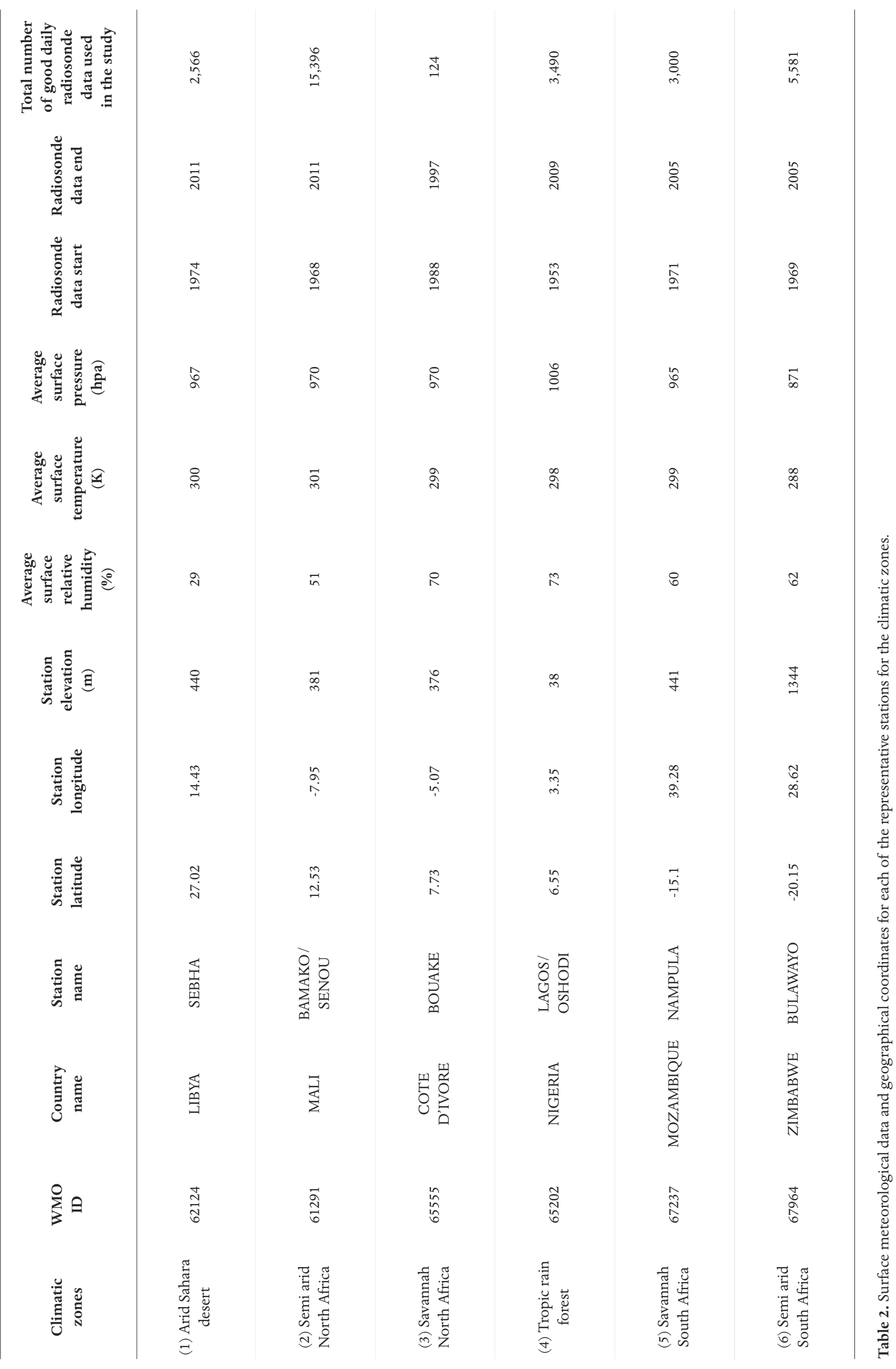


for each radio-sounding profile. The procedures for the two models used in this work are given by [Salonen, and Uppala 1991] and ITU-R model [ITU-R 2009a, ITU-R 2009b, P.840-4] and this method has been used in previous work for Nigeria and Tropical wet location Yaounde, Cameroon [Omotosho and Babtude 2010, Omotosho et al. 2011] respectively.

\subsection{Slobin}

Using the expression provided by Slobin, the specific attenuation of radio waves by clouds at different wavelengths is given by the following expression:

$$
\sigma=\frac{4.343 \times M \times 10^{0.0122(291-T)-1} \times 1.16}{\lambda^{2}},
$$

where $\sigma$ is the specific attenuation caused by clouds $(\mathrm{dB} / \mathrm{km}), \mathrm{M}$ is the cloud water particle density $(\mathrm{g} / \mathrm{m} 3)$, $\mathrm{T}$ is the cloud temperature $\left({ }^{\circ} \mathrm{K}\right)$, and $\lambda$ is the wavelength of the radio wave $(\mathrm{cm})$.

The cloud particle temperature is the temperature of the region in which the cloud exists, measured at the height of the cloud. The mean cloud temperature and cloud top height were retrieved from the International Satellite Cloud Climatology Project (ISCCP).

\subsection{Cloud Liquid Water Content (LWC) at different} height level

The formation of cloud is related to the high relative humidity whereby the radiosonde data indicate the presence of LWC depending on whether the relative humidity has exceeded its critical value. Cloud is formed as the relative humidity exceeds $95 \%$ and the phase is determined by the temperature profile. The LWC for each height level can be calculated by the following expression:

$$
\operatorname{LWC}_{a d}(h)=\int \rho(z) \frac{C_{p}}{L}\left(\Gamma_{d}-\Gamma_{s}\right) d z
$$

where: $\rho(z)=$ air density; $C_{p}=$ specific heat at constant pressure; $L=$ latent heat of vaporization; $\Gamma_{d}=$ dry adiabatic lapse rate; $\Gamma_{s}=$ moist adiabatic lapse. The adiabatic condition produces a maximum value of the LWC that is given by Equation (3) due to the circulation of air mass accompanied by precipitation and freezing temperatures.

$$
\mathrm{LWC}=\mathrm{LWC}_{a d}(1.239-0.145 \ln \Delta h)
$$

where $\Delta h=$ height above the cloud base. LWC is then calculated at each pressure level at a particular radiosonde ascent. Integrating the LWC profile over height, the total value of LWC is obtained at each ascent [Chakraborty and Animesh 2012]

\section{Results and discussion}

\subsection{Low cloud cover and frequency of precipitation}

In this section, we present and discuss the annual low cloud type, monthly variation of low cloud amount, and monthly variation of precipitation frequency average results from 1970 to 1996 for the six climatic zones. These quantities are important for the basic understanding of the cloud impairment of radio wave signals in the six zones. Figure 2 presents the annual distribution of the five low cloud types: stratus $(\mathrm{St})$, stratocumulus $(\mathrm{Sc})$, cumulus $(\mathrm{Cu})$, cumulonimbus $\mathrm{Cb}$ ) and nimbostratus $(\mathrm{Ns})$. The amount of all low cloud types was highest in the tropical rain forest (36.3\%) because of the higher incidences of $S c, C b$ and $\mathrm{Cu}$ clouds, followed in decreasing order by the South African savannah (29\%), semi-arid South Africa (21.5\%), the North African savannah (18.6\%), the arid-Sahara desert (11\%) and semi-arid North Africa (5.1\%). Stratocumulus clouds are well-known to produce drizzle or light precipitation, and their presence may precede or follow more severe weather. Cumulus clouds are the product of free convective air mass instability, and they can become more storm-like, towering and vertical, thereby building into cumulonimbus, whose continued upward growth suggests showers and other precipitation. Cumulonimbus clouds are violent; when they produce rain, it is often associated with lightning and thunderstorms. Cumulus and cumulonimbus clouds have been reported by Slobin to contain substantial cloud liquid water: up to approximately $0.67 \mathrm{~g} / \mathrm{m}$ and $1 \mathrm{~g} / \mathrm{m}^{3}$, respectively [Slobin 1982].

Figures 3 and 4 show the monthly variation of precipitation frequency and low cloud cover for the period 1970 to 1996 in the six climatic zones. Figures 3 and 4 have exactly the same shape, which means that the frequency of precipitation and low cloud cover are positively correlated. The monthly low cloud cover reaches its maximum in August in the four climatic zones in northern Africa (the arid Sahara desert, semiarid North Africa, North African savannah, and tropical rain forest), whereas it reaches its minimum in August in the southern climatic zones (South African savannah and semi-arid South Africa maximum in January). The monthly precipitation frequency reaches its minimum in August in the south, but it peaks in the north, except for two zones: the arid Sahara desert, which reaches its maximum in January, and the tropical rain forest, which has two maxima in April and October. These maxima correspond to the rainy season in the tropical rain forest. The period of higher cloud cover in the climatic zones corresponds to the rainy season for all six zones. 

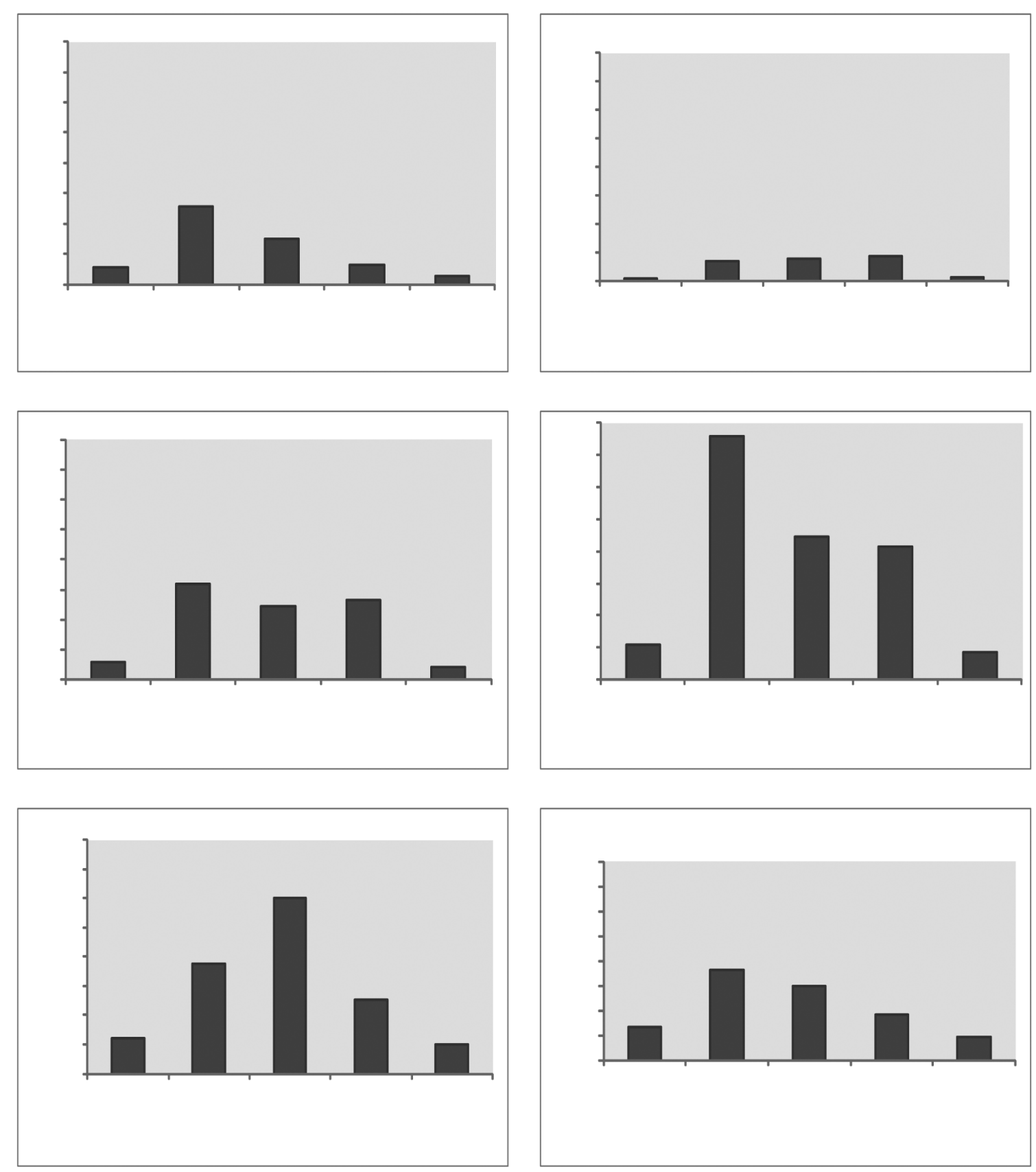

Figure 2. Annual low cloud distribution in the six major climatic zones of Africa.

\subsection{Percentage of clear sky and total cloud cover}

In this section, we present the monthly clear sky variation and monthly total cloud cover variation (low + middle + high cloud cover) from 1970 to 1996 for the six major climatic zones of Africa. Figures 5 and 6 present the clear sky and total cloud cover results. The two graphs are negatively correlated, with the same shape in the opposite direction. This result was expected because the month with the greatest amount of clear sky often corresponds to a period of little or no rainfall because rainfall is often preceded by the formation of certain types of cloud. The highest monthly amount of clear sky occurred in semi-arid South Africa (67.8\%), followed in decreasing order by the arid Sahara desert (48\%), the South African savannah (43.2\%), the North
African savannah (31.9\%), semi-arid North Africa (29\%) and the tropical rain forest (17.5\%). These patterns of monthly clear sky in the six zones were expected; dust storms in the arid Sahara desert zone reduce the monthly values, but these events are rare in semi-arid South Africa. The tropical rain forest zone has the least clear sky because of its high all-year rainfall pattern and highest rainfall accumulation (between 1,800 and 3,000 $\mathrm{mm}$ ), as shown in Table 1.

The maximum total cloud cover for the South African savannah and semi-arid South Africa zones occurs in January, with values of $75.4 \%$ and $62.9 \%$, respectively. Similarly, the northern semi-arid North Africa and North African savannah zones experience their maximum total cloud cover in August, with values 

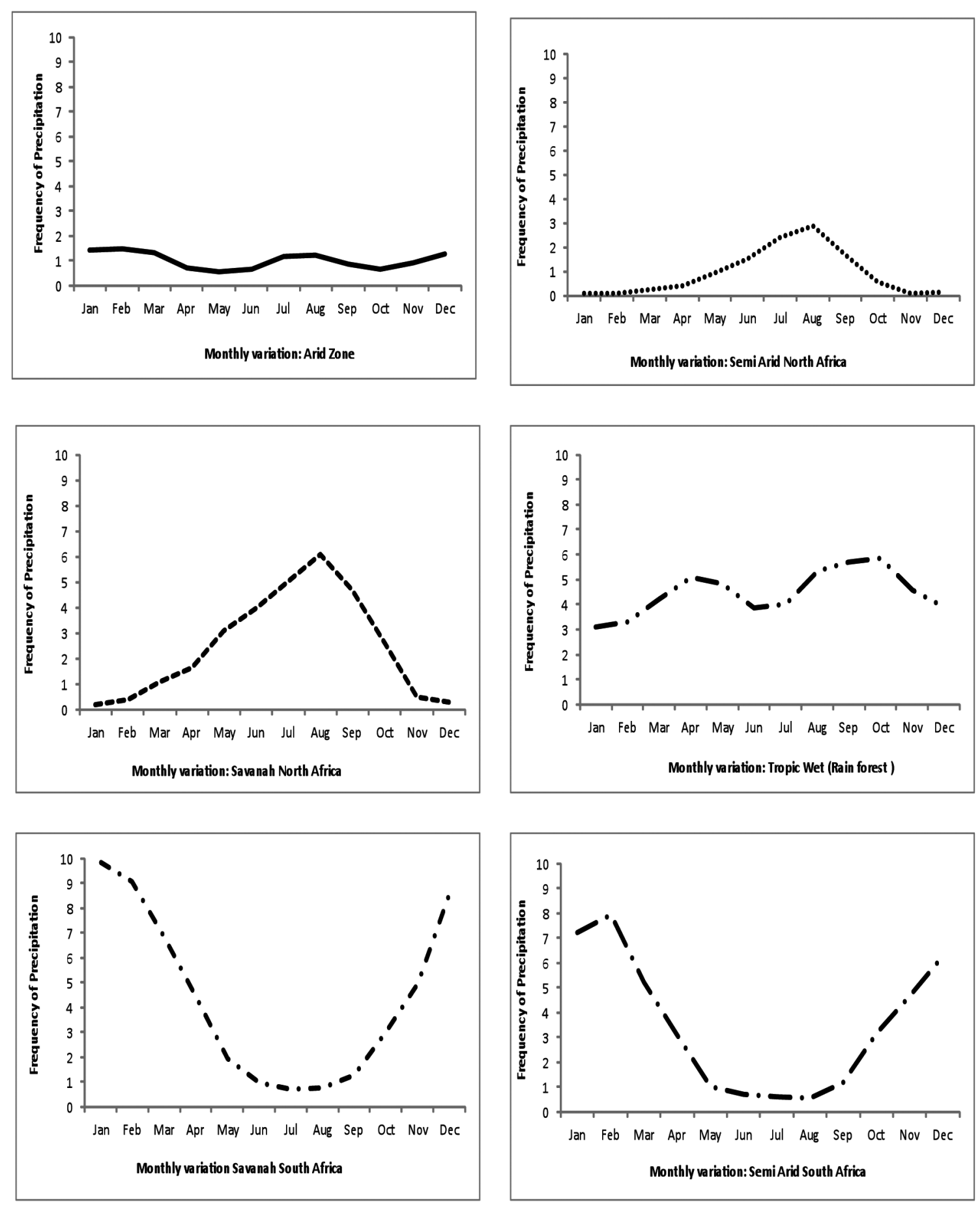

Figure 3. Monthly distribution of precipitation frequency in the six climatic zones.

of $68.9 \%$ and $81.4 \%$, respectively. The maximum total cloud cover in the tropical rain forest differs from that in the other zones, with two peak values of $72.2 \%$ and $74.2 \%$ in April and October, respectively. The arid Sahara desert has its maximum total cloud cover in December $(34.8 \%)$, which is the lowest among the six climatic zones (this result is shown in Figure 3). The Sahara zone also has the lowest frequency of precipitation. It is interesting to note that the months of maximum total cloud cover correspond to the month of maximum rainfall in the South African savannah and semi-arid south Africa (January), semi-arid North Africa and the North African savannah (August), the tropical rain forest (April and October) and the arid Sahara desert (December) [Adeyewa and Nakamura 2003].

Table 3 presents the annual amount of clear sky, frequency of precipitation and cloud cover statistics for the six climatic zones. The annual total cloud cover is highest in the tropical rain forest (97.9\%), followed in decreasing order by the North African savannah (85.4\%), the South African savannah (72.7\%), semi-arid North Africa (62.2\%), semi-arid South Africa (49.9\%) and the arid Sahara desert $(37.7 \%)$. The annual frequency of precipitation is highest in the tropical rain forest and the South African savannah 

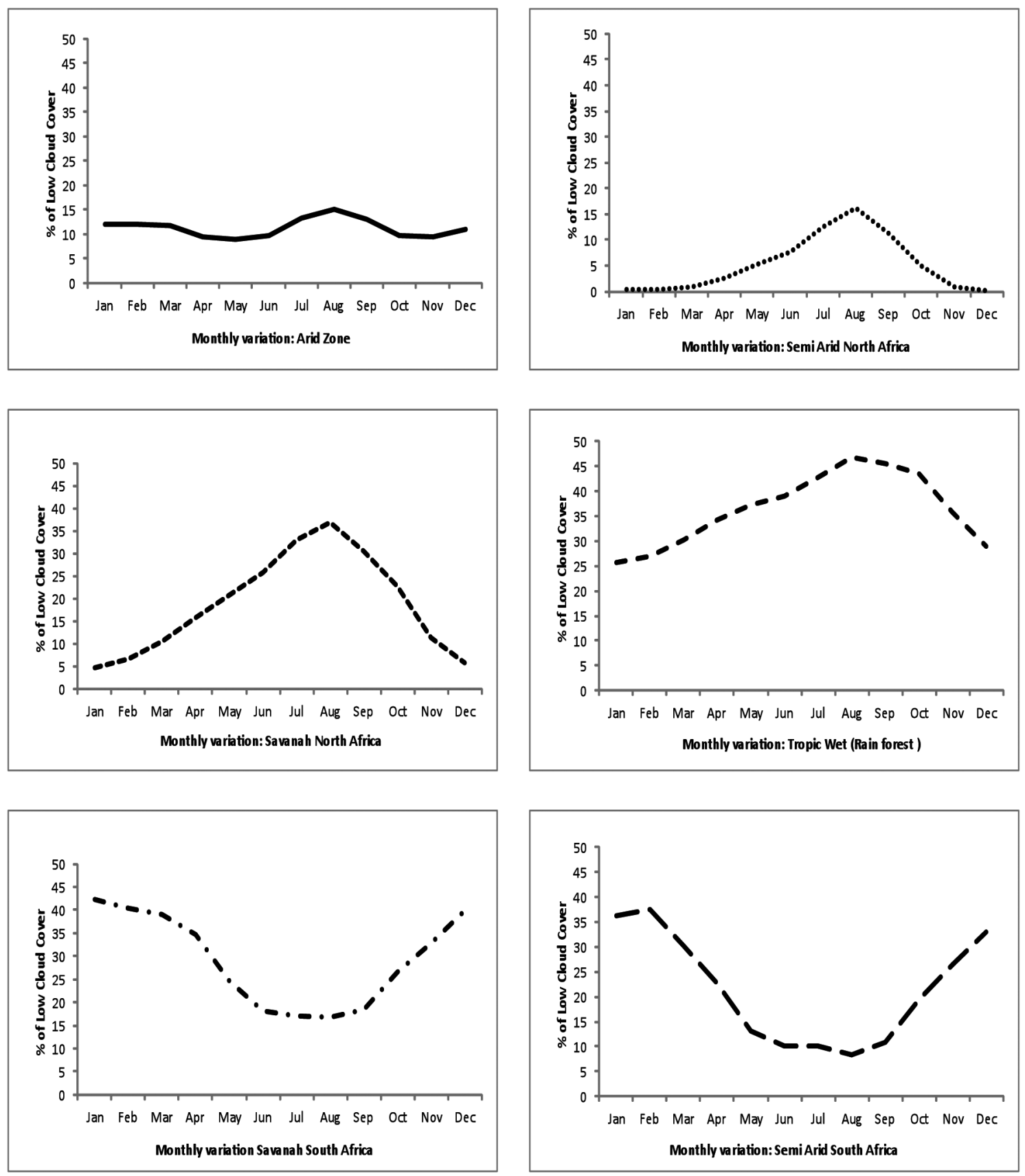

Figure 4. Monthly distribution of low cloud cover in the six major climatic zones.

$(4.5 \%)$, followed in decreasing order by semi-arid South Africa (3.5\%), the North African savannah (2.5\%), the arid Sahara desert (1\%) and semi-arid North Africa (0.9\%). The annual amount of clear sky is highest in the arid Sahara desert $(40.4 \%)$, followed in descending order by semi-arid South Africa (32.1\%), semi-arid North Africa $(19.8 \%)$, the South African savannah (17.5\%), the North African savannah (12.7) and the tropical rain forest (8\%).

\subsection{Average cloud temperature, seasonal and annual} cloud base, top height and cloud depth

Table 4 presents the cloud temperature results for the six climatic zones. This value is an important input parameter for calculating the specific attenuation of radio waves within the cloud at different wavelengths (see
Equation 13) [Slobin 1982]. The cloud temperature is higher in the arid Sahara desert $(281 \mathrm{~K})$ and lower in semiarid South Africa $(245 \mathrm{~K})$. The lowest seasonal cloud base height is found in the tropical rain forest $(356 \mathrm{~m})$, with an average cloud temperature of $261 \mathrm{~K}$. The lowest annual cloud top height and cloud depth occur in the arid Sahara desert, whereas the highest cloud top height and cloud depth are found in the North African savannah and the tropical rain forest, followed in descending order by semiarid North Africa, the South African savannah and semiarid South Africa. The results in Tables 3 and 4 reveal that a radio wave signal passing through clouds over the tropical rain forest or the North African savannah will travel a longer distance because these two zones have the greatest cloud depth and total cloud cover. 

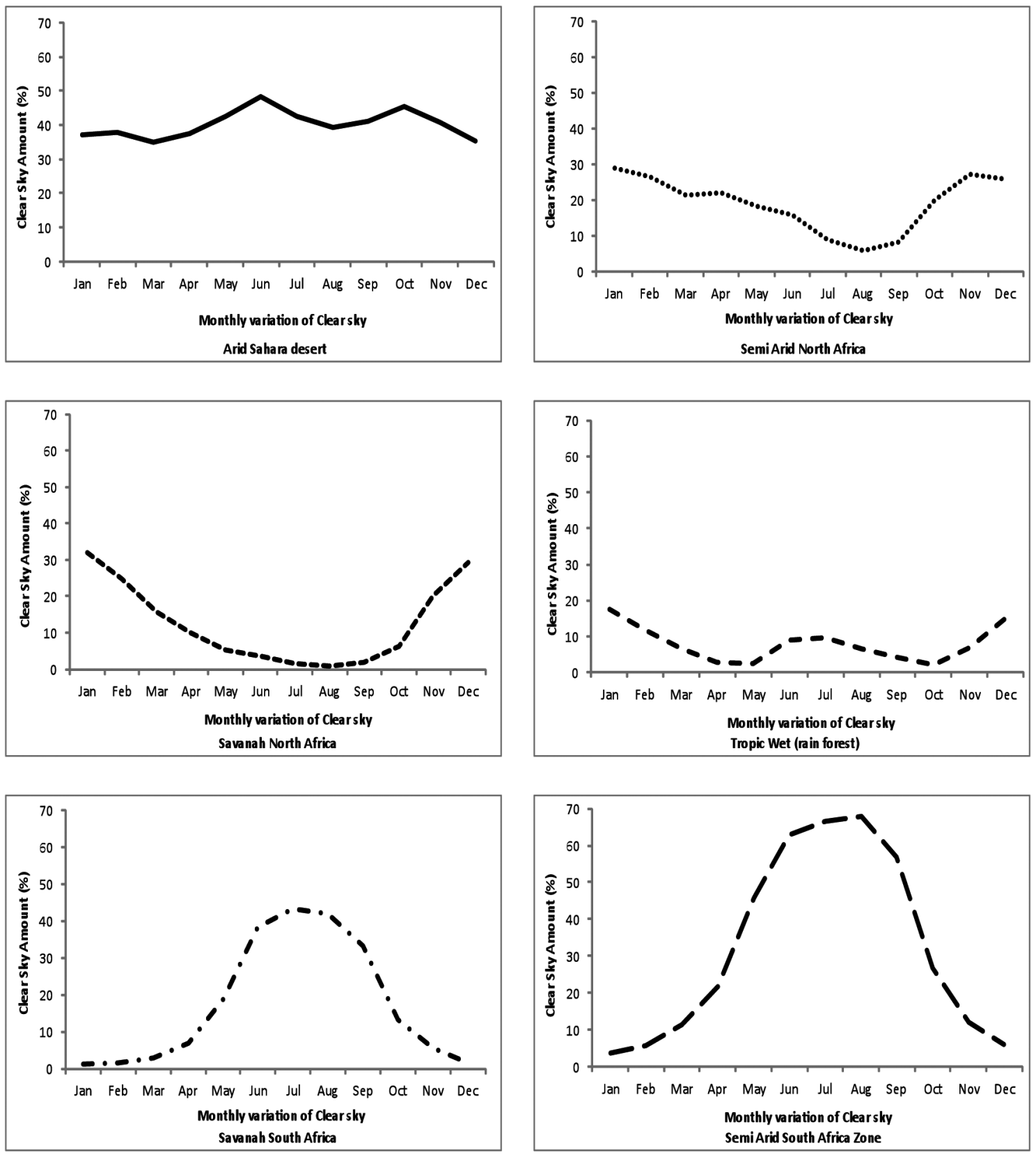

Figure 5. Monthly clear sky distribution in the six major climatic zones.

\subsection{Monthly variation of freezing height}

Figure 7 presents the monthly variation of freezing (the $0^{\circ} \mathrm{C}$ isothermal height) derived from daily radiosonde data for the six major climatic zones. The monthly distribution of the $0^{\circ} \mathrm{C}$ isothermal height in the South African savannah and semi-arid South Africa follows exactly the same curve shape as the total cloud cover. The freezing height maximum for the two zones occurred in February at $4.61 \mathrm{~km}$ and $3.57 \mathrm{~km}$, respectively, which corresponds to the same period as the maximum total cloud cover. However, for the Arid Sahara desert zone, the pattern follows a normal distribution, and the maximum freezing height occurs in August at $4.46 \mathrm{~km}$. The freezing heights in semi-arid North Africa and the North African savannah have three different peaks, and their maxima occur in November and June at $4.43 \mathrm{~km}$ and $4.54 \mathrm{~km}$, respectively. The tropical rain forest freezing height distribution reaches its minimum in July at $4.53 \mathrm{~km}$. The tropical rainforest zone has the highest $0^{\circ} \mathrm{C}$ isothermal height of approximately $4.8 \mathrm{~km}$, and it reaches its minimum in July during the period of maximum low cloud cover (Figure 4), which corresponds to the rainy season in the zone.

\subsection{Total cloud liquid water content derived from ra-} diosonde data

Figures 8 and 9 present the daily TCLWC and cumulative distribution of the total cloud liquid water content from $0.01 \%$ to $100 \%$ exceedance for the six climatic zones. In Figure 9, the cumulative distribution of 

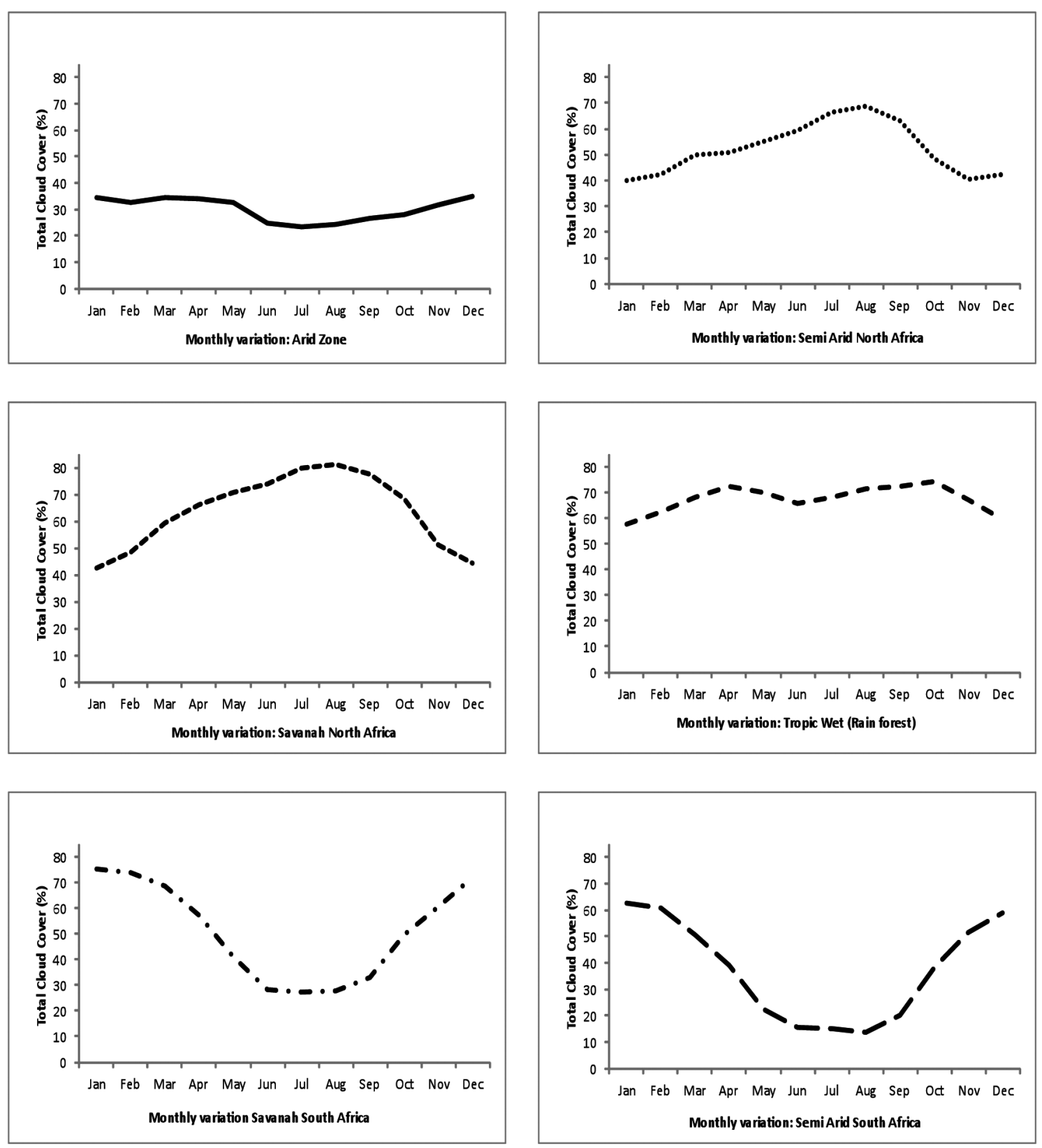

Figure 6. Monthly distribution of total cloud cover in the six major climatic zones.

the TCLWC was plotted on the same graph with the data of the ITU Radiocommunication Study Group 3 [2011], as described in Section 3.2.2, for comparison. The daily TCLWC could be as high as $4.5 \mathrm{~kg} / \mathrm{m}^{2}$ in the tropical rain forest, and it could exceed $4.0 \mathrm{~kg} / \mathrm{m}^{2}$ $0.01 \%$ of the time. Figure 9 shows that the values of the TCLWC recommended by ITU underestimate the values of the TCLWC in all six climatic zones at all percentages of exceedance. Between $0.01 \%$ and $10 \%$ exceedance, the underestimation is as follows: the arid Sahara desert, $37 \%$ to $86 \%$; semi-arid North Africa, $37 \%$ to $88 \%$; the North African savannah, $32 \%$ to $86 \%$; the tropical rain forest, $46 \%$ to $90 \%$; the South African savannah, $37 \%$ to $82 \%$; and semi-arid South Africa, $34 \%$ to $81 \%$. The highest underestimation occurs in the tropical rain forest climatic zone.

\subsection{Cloud attenuation}

In conjunction with the expression provided by Slobin, the average cloud temperature shown in Table 4 was used to compute the specific cloud attenuation of radio waves from $12 \mathrm{GHz}$ to $100 \mathrm{GHz}$ for the six climatic zones. The results are presented in Table 5. The specific cloud attenuation decreases with increasing cloud temperature, which is highest for the arid Sahara desert $(281 \mathrm{~K})$; therefore, it has the lowest specific cloud attenuation of $7.4 \mathrm{~dB} / \mathrm{km}$ at $100 \mathrm{GHz}$. This result was expected for a desert climatic zone. The North African savannah has the lowest cloud temperature $(238 \mathrm{~K})$; consequently, it has the highest specific cloud attenuation of $25.1 \mathrm{~dB} / \mathrm{km}$ at $100 \mathrm{GHz}$, followed in decreasing order by semi-arid South Africa $(245 \mathrm{~K})$ at $20.6 \mathrm{~dB} / \mathrm{km}$, the South African savannah 
CLOUD ATTENUATION FOR Ka AND V BANDS

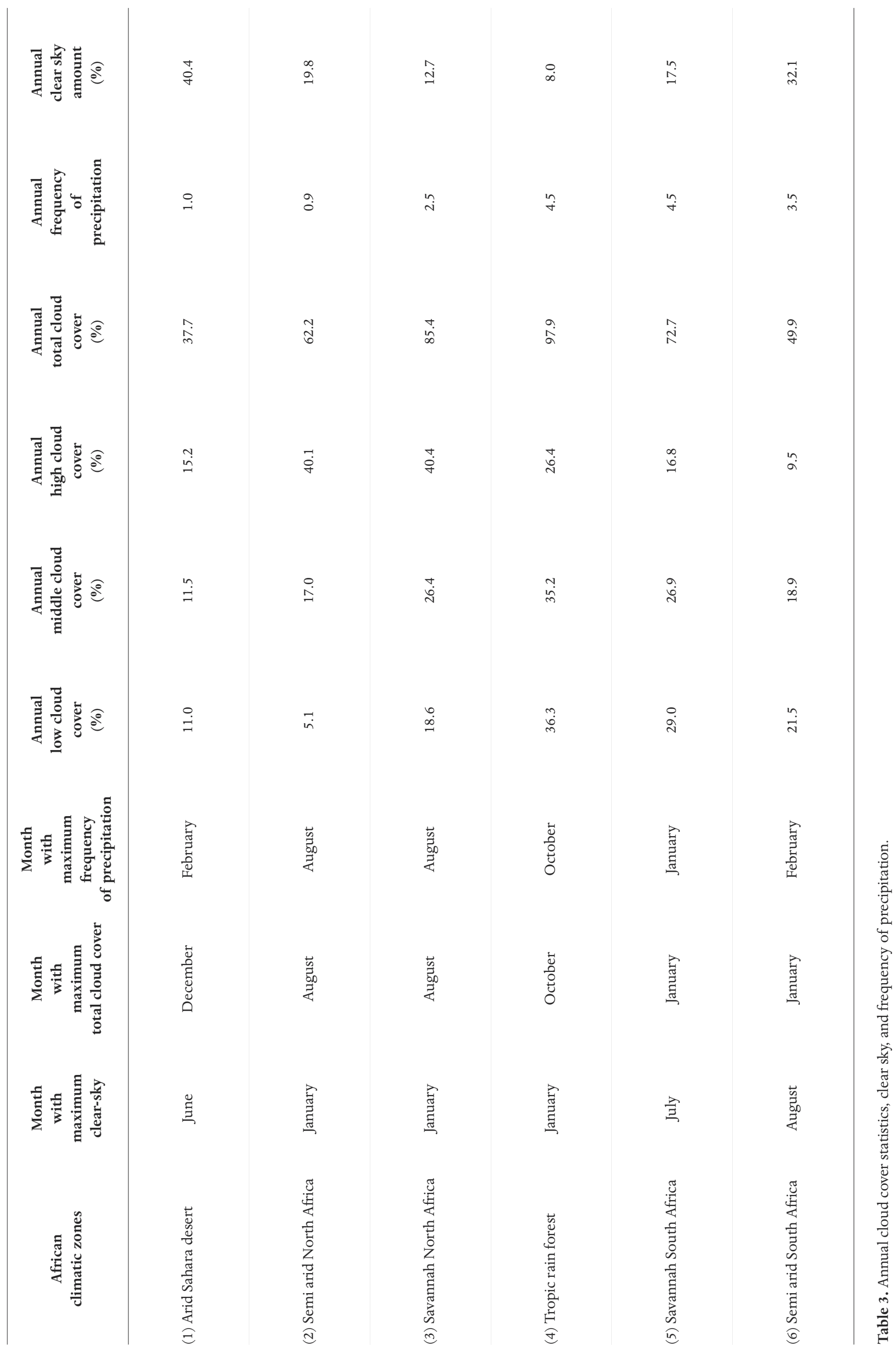


OMOTOSHO ET AL.

\begin{tabular}{|c|c|c|c|c|c|c|c|}
\hline \multicolumn{2}{|c|}{ 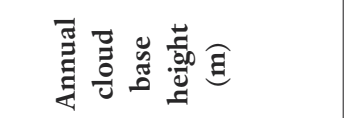 } & 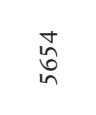 & ڤ̊ & $\begin{array}{l}\overrightarrow{0} \\
\exists\end{array}$ & $\begin{array}{l}\stackrel{q}{+} \\
\stackrel{G}{=}\end{array}$ & $\stackrel{\circ}{\circ}$ & 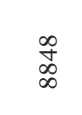 \\
\hline \multicolumn{2}{|c|}{ 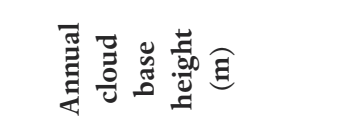 } & $\tilde{\alpha}$ & 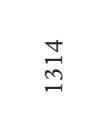 & $\hat{o}$ & 苧 & $\vec{f}$ & $\stackrel{m}{n}$ \\
\hline \multicolumn{2}{|c|}{ 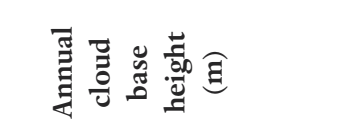 } & 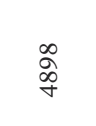 & $\begin{array}{l}\infty \\
\infty \\
\infty \\
\infty\end{array}$ & $\begin{array}{l}\stackrel{0}{\circ} \\
\stackrel{0}{0}\end{array}$ & $\begin{array}{l}\text { 寸 } \\
\stackrel{0}{0} \\
\end{array}$ & $\underset{\infty}{\stackrel{N}{N}}$ & $\stackrel{\hat{m}}{\infty}$ \\
\hline \multirow{3}{*}{ 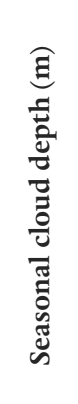 } & 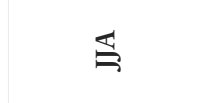 & $\begin{array}{l}\stackrel{\circ}{\circ} \\
\stackrel{f}{2}\end{array}$ & $\begin{array}{l}\stackrel{\infty}{0} \\
\stackrel{0}{0}\end{array}$ & $\underset{f}{\stackrel{O}{J}}$ & $\underset{\infty}{\stackrel{N}{N}}$ & 芒 & $\begin{array}{l}\stackrel{2}{ } \\
\text { そ̆ }\end{array}$ \\
\hline & $\sum_{\Sigma}^{\Sigma}$ & 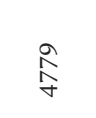 & $\begin{array}{l}+ \\
\infty \\
\infty \\
\infty\end{array}$ & 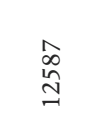 & 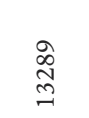 & $\overrightarrow{\bar{\infty}}$ & $\begin{array}{l}\stackrel{\infty}{\infty} \\
\infty\end{array}$ \\
\hline & 党 & $\begin{array}{l}\hat{b} \\
\text { bे }\end{array}$ & $\underset{i}{\stackrel{+}{N}}$ & $\begin{array}{l}\stackrel{2}{\pi} \\
\text { a }\end{array}$ & $\begin{array}{l}\stackrel{q}{d} \\
=\end{array}$ & 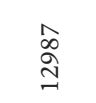 & 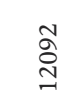 \\
\hline \multirow{4}{*}{ 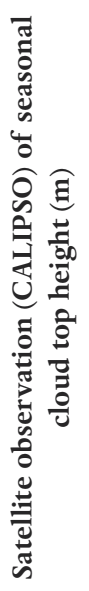 } & ż & $\begin{array}{l}\text { D } \\
\text { in }\end{array}$ & $\begin{array}{l}\text { ڤ్ } \\
\text { }\end{array}$ & $\begin{array}{l}\stackrel{0}{0} \\
ٌ\end{array}$ & 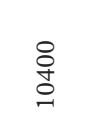 & $\stackrel{\tilde{\sigma}}{\hat{\sigma}}$ & $\underset{\infty}{\stackrel{+}{+}}$ \\
\hline & 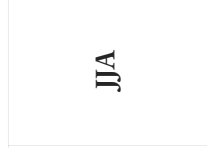 & $\underset{i n}{\stackrel{\infty}{n}}$ & $\stackrel{\infty}{\stackrel{\infty}{]}}$ & $\begin{array}{l}\text { : } \\
\text { ত্ }\end{array}$ & $\begin{array}{l}\infty \\
\stackrel{\infty}{a}\end{array}$ & $\stackrel{Y}{i}$ & $\begin{array}{l}\infty \\
\stackrel{\alpha}{\sigma}\end{array}$ \\
\hline & $\sum_{i}^{\sum}$ & $\hat{\tilde{n}}$ & 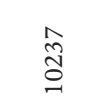 & $\begin{array}{l}\infty \\
\stackrel{\omega}{\sim} \\
\stackrel{\sim}{n}\end{array}$ & 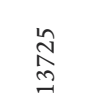 & ڤ్ & $\begin{array}{l}\hat{n} \\
\hat{\alpha}\end{array}$ \\
\hline & 岂 & : & $\underset{\substack{0 \\
\wedge}}{0}$ & $\begin{array}{l}\text { న్ } \\
\text { }\end{array}$ & 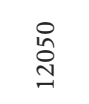 & 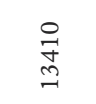 & $\begin{array}{l}\stackrel{8}{0} \\
\stackrel{0}{-}\end{array}$ \\
\hline \multirow{6}{*}{ 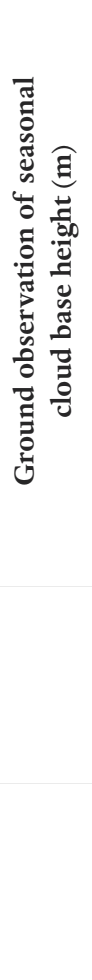 } & ż & గ్ర & $\underset{\square}{\stackrel{t}{\circ}}$ & in & $\begin{array}{l}\text { L } \\
n\end{array}$ & oे & 占 \\
\hline & $\Xi$ & $\stackrel{\infty}{h}$ & 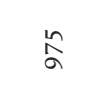 & م̂ & $\stackrel{\nabla}{\forall}$ & \&̊ㅁ & $\tilde{\mathfrak{q}}$ \\
\hline & $\sum_{\sum}$ & $\stackrel{\infty}{\not}$ & 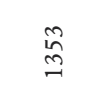 & $\vec{R}$ & $\begin{array}{l}\stackrel{\circ}{\gamma} \\
\stackrel{\gamma}{7}\end{array}$ & $\underset{\underset{+}{+}}{+}$ & $\stackrel{\infty}{\stackrel{\infty}{+}}$ \\
\hline & 壳 & $\stackrel{\varrho}{\stackrel{\varrho}{\theta}}$ & $\begin{array}{l}\mathscr{0} \\
\stackrel{\infty}{\rightarrow}\end{array}$ & I & $\stackrel{\ominus}{\vec{\gamma}}$ & $\stackrel{\widetilde{Y}}{\mathscr{Y}}$ & $\stackrel{\infty}{\stackrel{\infty}{n}}$ \\
\hline & 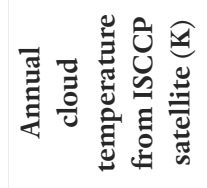 & $\vec{\sim} \underset{\sim}{\vec{\infty}}$ & $\stackrel{\circ}{\sim}$ & $\stackrel{\infty}{\sim}$ & $\overrightarrow{\mathrm{D}}$ & $\overrightarrow{\tilde{N}}$ & $\stackrel{\text { 吕 }}{\sim}$ \\
\hline & 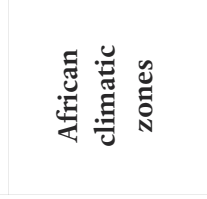 & 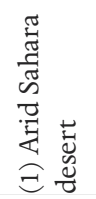 & 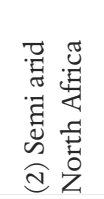 & 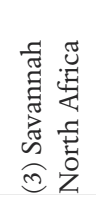 & 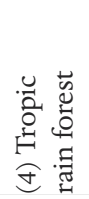 & 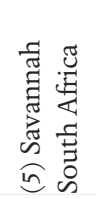 & 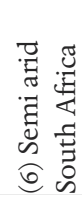 \\
\hline
\end{tabular}



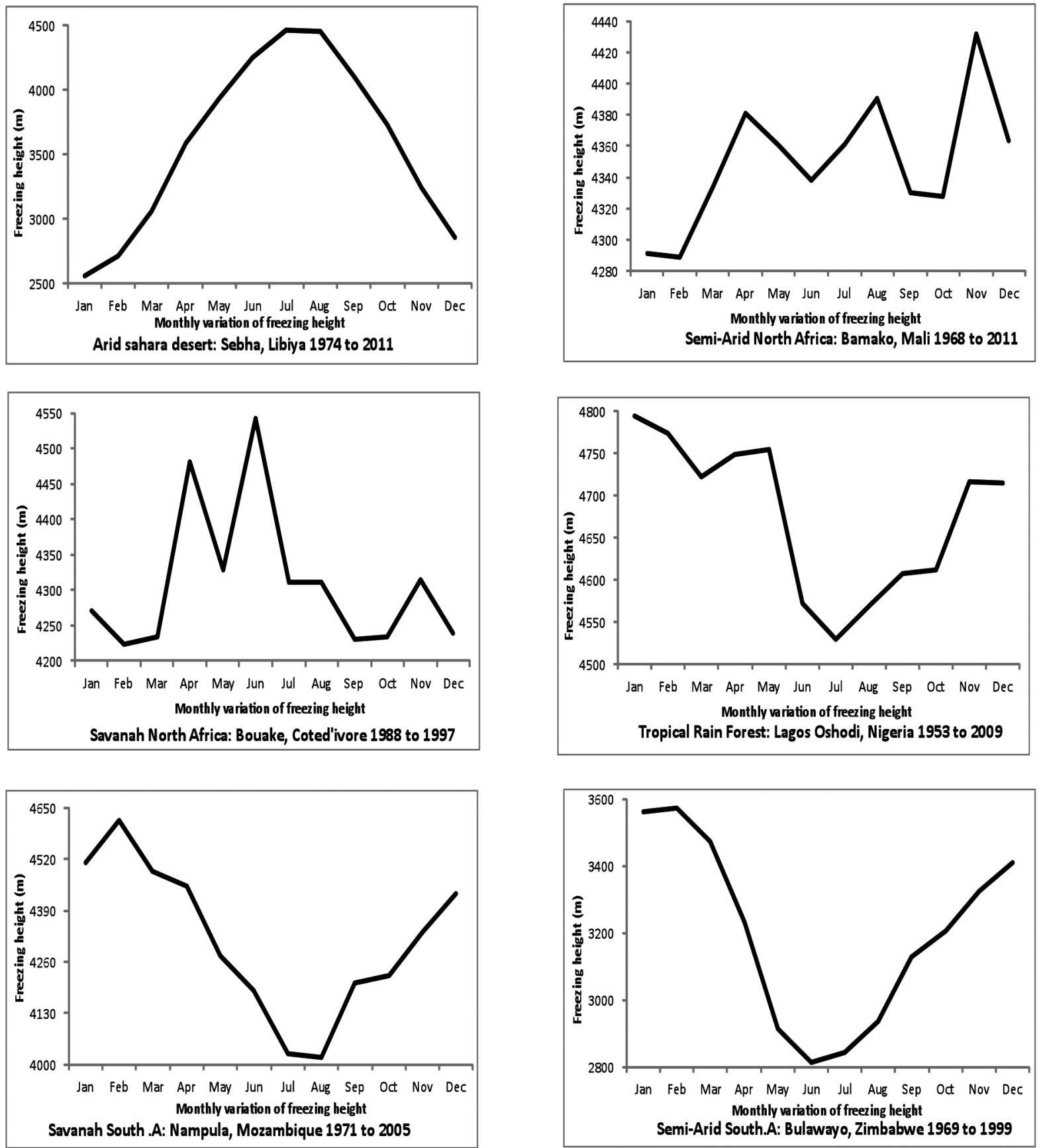

Figure 7. Monthly variation of $0^{\circ} \mathrm{C}$ isothermal height derived from daily radiosonde data.

$(251 \mathrm{~K})$ at $17.1 \mathrm{~dB} / \mathrm{km}$, semi-arid South Africa $(260 \mathrm{~K})$ at $13.4 \mathrm{~dB} / \mathrm{km}$ and the tropical rain forest $(260 \mathrm{~K})$ at $12.9 \mathrm{~dB} / \mathrm{km}$.

Figures 10 and 11 present the results of the cumulative distribution of cloud attenuation at 30 and 50 $\mathrm{GHz}$ obtained from radiosonde measurements. The same figure also shows the data obtained from the ITU-R model for the six climatic zones for comparison. The ITU-R model underestimates the cloud attenuation at all six zones because of the lower values of TCLWC predicted by its database. Between $0.01 \%$ and $10 \%$ exceedance, the difference at $30 \mathrm{GHz}$ and $50 \mathrm{GHz}$ is as high as $2 \mathrm{~dB}$ and $4.7 \mathrm{~dB}$ in the arid Sahara desert, $1.3 \mathrm{~dB}$ and $3.0 \mathrm{~dB}$ in semi-arid North Africa, $1.3 \mathrm{~dB}$ and
$1.5 \mathrm{~dB}$ in the North African savannah, $2 \mathrm{~dB}$ and $3.6 \mathrm{~dB}$ in the tropical rain forest, $1.3 \mathrm{~dB}$ and $2.9 \mathrm{~dB}$ in the South African savannah, and $0.9 \mathrm{~dB}$ and $2.6 \mathrm{~dB}$ in semiarid South Africa, respectively. The underestimation is highest in the arid Sahara desert. The highest similarity in the results between the radiosonde measurements and the ITU-R model was obtained in the North African savannah, with a difference of $1.3 \mathrm{~dB}$ and 1.5 $\mathrm{dB}$ at 30 and $50 \mathrm{GHz}$, respectively. Overall, the maximal cloud attenuation was observed for the tropical rain forest at all percentages of time and at both frequencies as a result of the high annual precipitation frequency (4.5), low annual amount of clear sky (8\%), high cloud depth $(10,937 \mathrm{~m})$, high $0^{\circ} \mathrm{C}$ isotherm height 

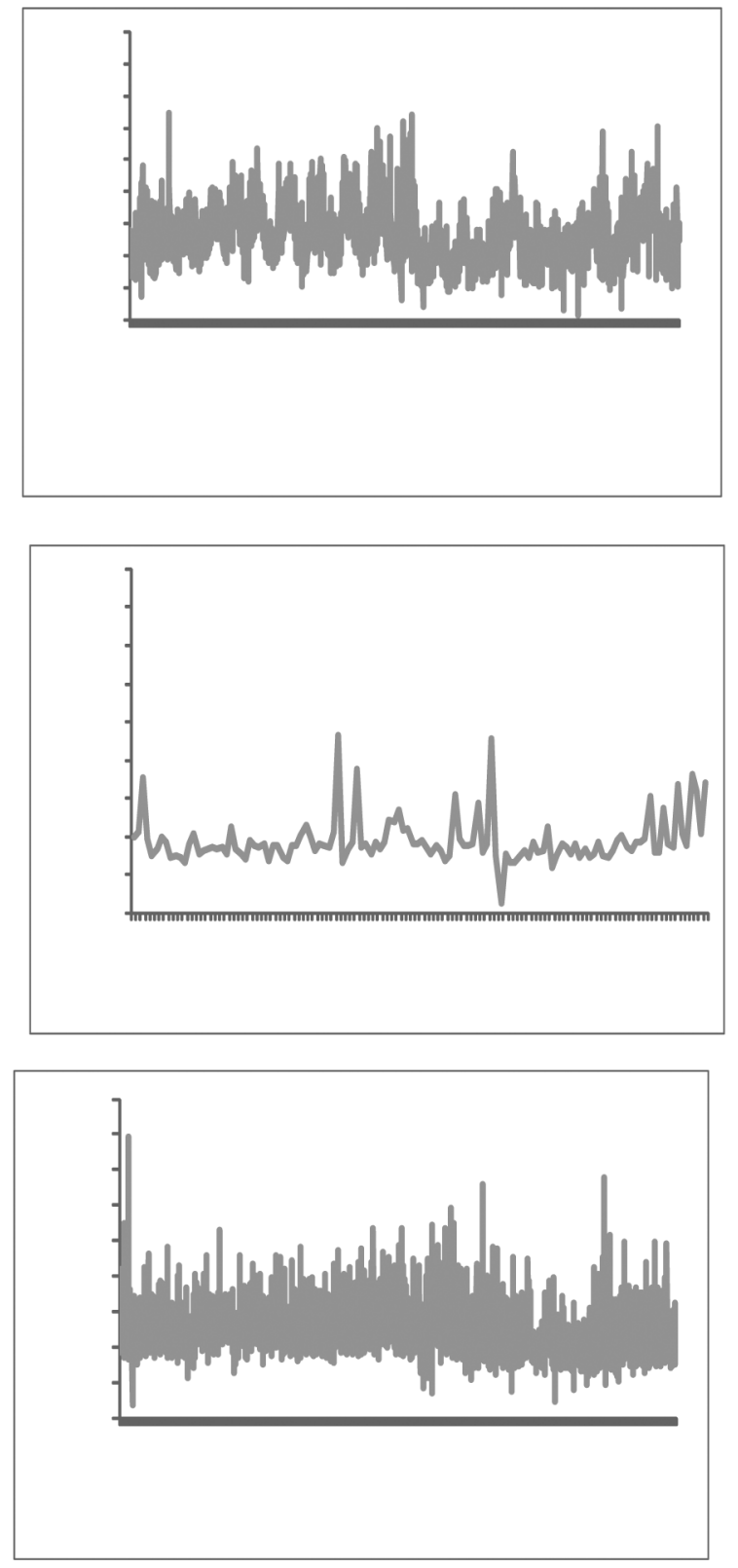
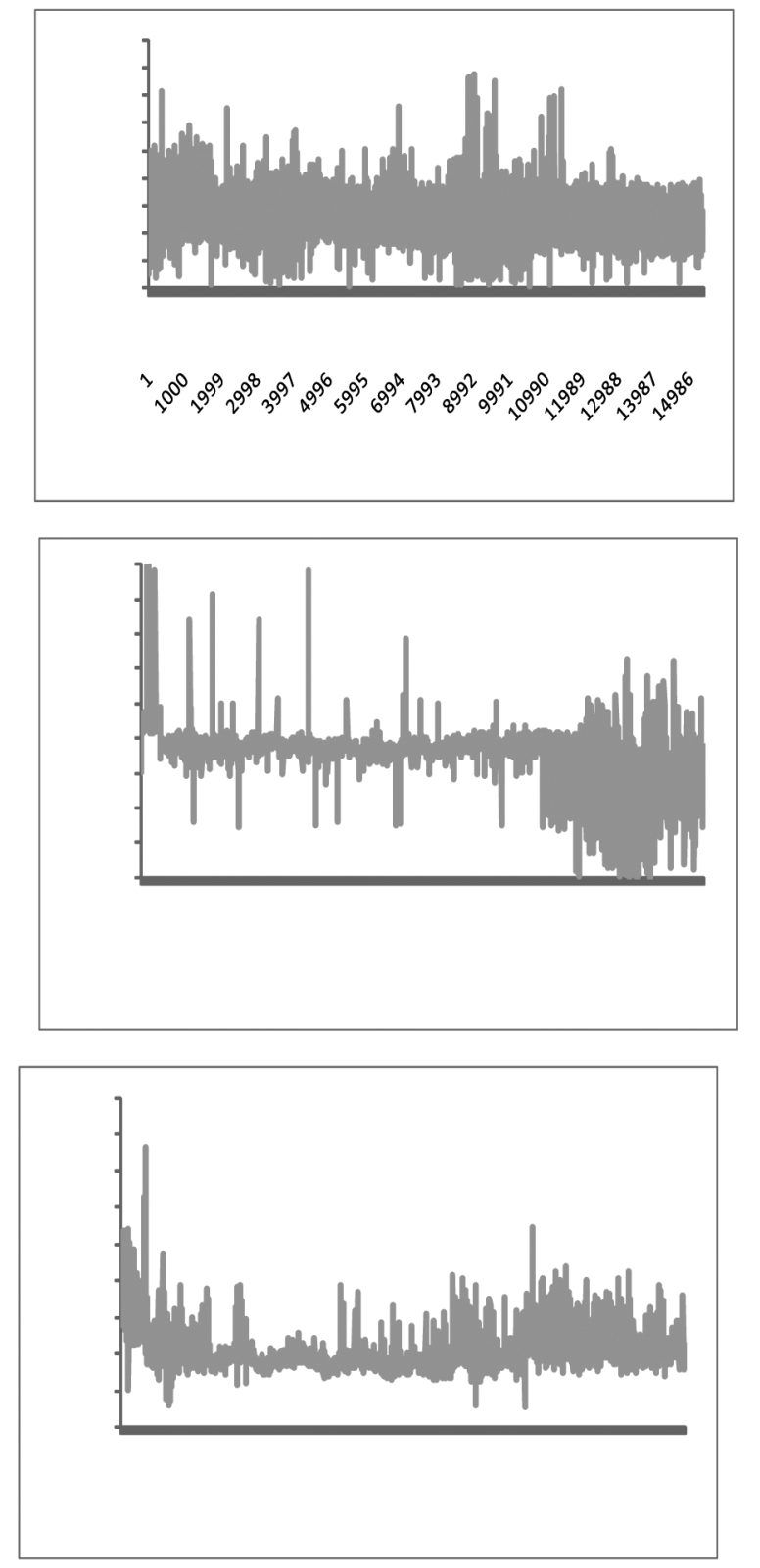

Figure 8. Daily distribution of total cloud liquid water content $\left(\mathrm{kg} / \mathrm{m}^{2}\right)$ obtained from radiosonde measurements in the six climatic zones.

$(4.7 \mathrm{~km})$, high TCLWC $\left(4.0 \mathrm{~kg} / \mathrm{m}^{2}\right.$ at $\left.0.01 \%\right)$ and low seasonal cloud base height $(356 \mathrm{~m})$.

\section{Conclusion}

Based on long-term data measurements (19532011), the cloud cover statistics, cloud base height, top height, cloud temperature, frequency of precipitation, freezing height, TCLWC and cloud attenuation have been determined for the six major climatic zones of Africa. The present results reveal a strong positive correlation between the monthly distribution of low cloud cover, cloud top height, cloud temperature, and frequency of precipitation at the six zones. The cumulative distribution of the TCLWC derived from radiosonde measurement at each climatic zone shows a departure from the TCLWC predicted by the ITU Study Group 3 data, with a difference of 32 to $90 \%$ for exceedance
$0.01 \%$ to $10 \%$ of the time. The underestimation of the TCLWC was highest in the tropical rain-forest. A comparison of the cloud attenuation cumulative distribution in the $\mathrm{Ka}$ and $\mathrm{V}$ bands reveals that the ITU-R model underestimates the cloud attenuation at 30 and $50 \mathrm{GHz}$ by $2.0 \mathrm{~dB}$ to $4.7 \mathrm{~dB}$ in the arid Sahara desert, $1.3 \mathrm{~dB}$ to $3.0 \mathrm{~dB}$ in semi-arid North Africa, $1.3 \mathrm{~dB}$ to 1.5 $\mathrm{dB}$ in the North African savannah, $2.0 \mathrm{~dB}$ to $3.6 \mathrm{~dB}$ in the tropical rain forest, $1.3 \mathrm{~dB}$ to $2.9 \mathrm{~dB}$ the South African savannah and $0.9 \mathrm{~dB}$ to $2.6 \mathrm{~dB}$ in semi-arid South Africa, respectively. Overall, the cloud attenuation is very high in the tropical rain-forest zone because of the high annual total cloud cover (98\%), high annual frequency of precipitation (4.5), low annual amount of clear sky (8\%), high cloud depth $(10,937 \mathrm{~m})$, high $0{ }^{\circ} \mathrm{C}$ Isotherm height $(4.7 \mathrm{~km})$, high TCLWC $\left(4.0 \mathrm{~kg} / \mathrm{m}^{2}\right.$ at $0.01 \%$ ) and low seasonal cloud base height (356 m). 

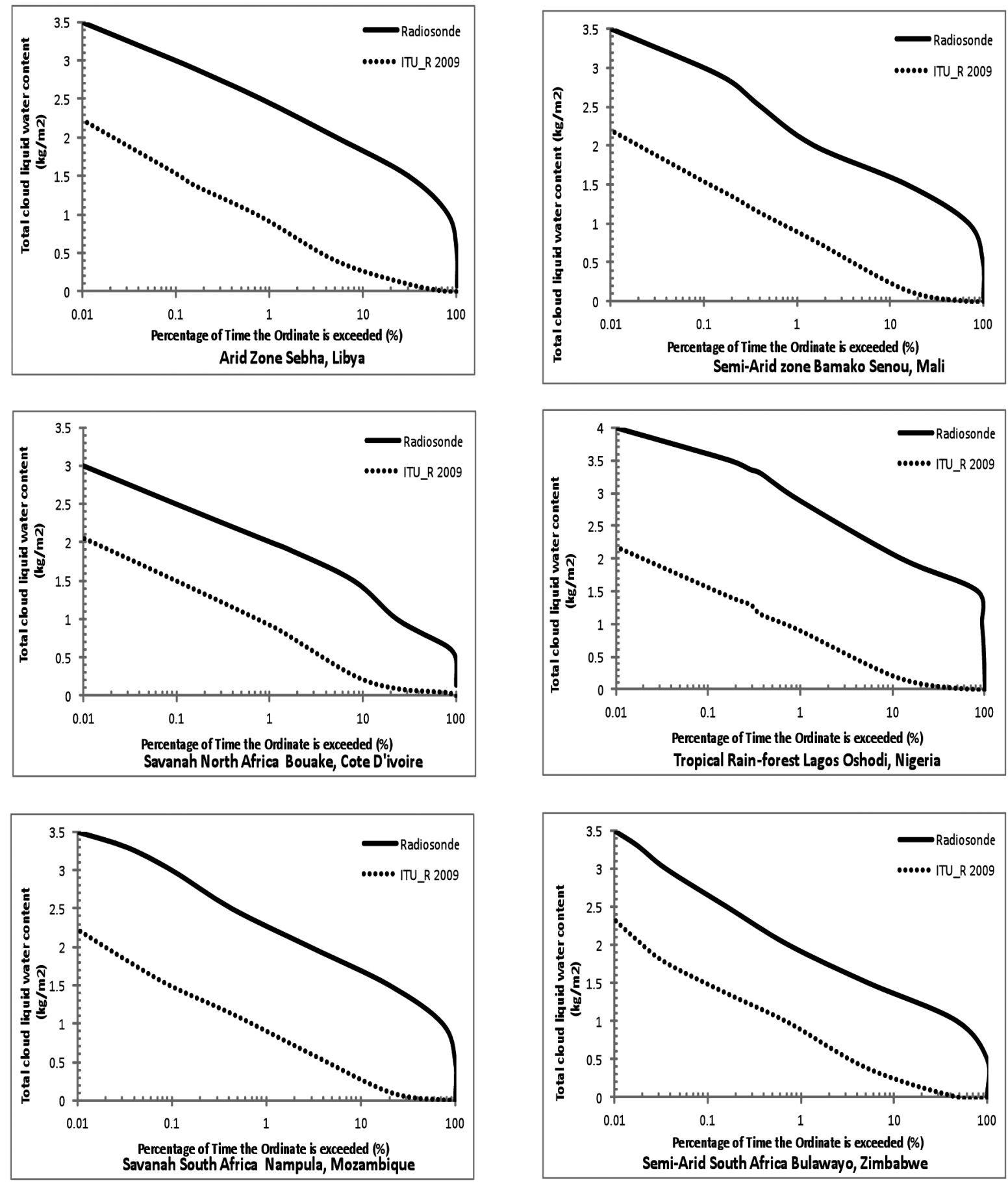

Figure 9. Cumulative distribution of total cloud liquid water content $\left(\mathrm{kg} / \mathrm{m}^{2}\right)$ obtained from radiosonde measurements; also shown is the data obtained from the ITU-R model for the six major climatic zones of Africa.

Acknowledgements. The support of Stephen G. Warren, and Carole J. Hahn, Department of Atmospheric Sciences University of Washington, Seattle, Washington 98195-1640 and Imke Durre, National Oceanic and Atmospheric Administration (NOAA) is gratefully acknowledged for download access to Surface-based Cloud Climatology Over Land and Ocean and the Integrated Global Radiosonde Archive data from their websites, respectively. The authors would also like to thank Universiti Kebangsaan Malaysia for the support of this work.

\section{References}

Adeyewa, Z.D., and K. Nakamura (2003). Validation of TRMM Radar Rainfall Data over Major Climatic Re- gions in Africa, J. Appl. Meteor., 42, 331-347.

Al-Ansari, K., P. Garcia, J.M. Riera and A. Benarroch (2003). One-year cloud attenuation results at 50 GHz, Electron. Lett., 39 (1), 136-137.

Altshuler, E., and R. Marr (1989). Cloud attenuation at millimetre wavelengths, IEEE Trans. Antennas Propag., 37 (11), 1473-1479.

Animesh, M., and S. Chakraborty (2009). Cloud Liquid Water Content and Cloud Attenuation Studies with Radiosonde Data at a Tropical Location, J. Infrared Milli Terahz Waves, 30, 367-373. 


\begin{tabular}{|c|c|c|c|c|c|c|c|}
\hline $\begin{array}{l}\text { Frequency } \\
\quad(\mathrm{GHz})\end{array}$ & $\begin{array}{l}\text { Band } \\
\text { name }\end{array}$ & $\begin{array}{c}\text { (1) Arid } \\
\text { Sahara desert } \\
\text { specific } \\
\text { attenuation } \\
(\mathrm{dB} / \mathrm{km})\end{array}$ & $\begin{array}{l}\text { (2) Semi arid } \\
\text { North Africa } \\
\text { specific } \\
\text { attenuation } \\
(\mathrm{dB} / \mathrm{km})\end{array}$ & $\begin{array}{c}\text { (3) Savannah } \\
\text { North Africa } \\
\text { specific } \\
\text { attenuation } \\
(\mathrm{dB} / \mathrm{km})\end{array}$ & $\begin{array}{l}\text { (4) Tropic } \\
\text { rain forest } \\
\text { specific } \\
\text { attenuation } \\
(\mathrm{dB} / \mathrm{km})\end{array}$ & $\begin{array}{c}\text { (5) Savannah } \\
\text { South Africa } \\
\text { specific } \\
\text { attenuation } \\
(\mathrm{dB} / \mathrm{km})\end{array}$ & $\begin{array}{l}\text { (6) Semi arid } \\
\text { South Africa } \\
\text { specific } \\
\text { attenuation } \\
(\mathrm{dB} / \mathrm{km})\end{array}$ \\
\hline 12 & $\mathrm{Ku}$ & 0.11 & 0.19 & 0.36 & 0.19 & 0.25 & 0.30 \\
\hline 14 & $\mathrm{Ku}$ & 0.14 & 0.26 & 0.49 & 0.25 & 0.33 & 0.40 \\
\hline 20 & $\mathrm{Ka}$ & 0.29 & 0.53 & 1.00 & 0.51 & 0.68 & 0.83 \\
\hline 30 & K & 0.66 & 1.20 & 2.26 & 1.16 & 1.54 & 1.86 \\
\hline 40 & $\mathrm{~V}$ & 1.18 & 2.14 & 4.01 & 2.06 & 2.73 & 3.30 \\
\hline 50 & V & 1.84 & 3.34 & 6.27 & 3.21 & 4.27 & 5.16 \\
\hline 75 & W & 4.15 & 7.51 & 14.10 & 7.23 & 9.60 & 11.61 \\
\hline 100 & W & 7.37 & 13.36 & 25.07 & 12.85 & 17.06 & 20.64 \\
\hline
\end{tabular}

Table 5. Specific cloud attenuation at various frequencies for the six climatic zones.

Chakraborty, S., and M. Animesh (2012). A Comparative Study of Cloud Liquid Water Content from Radiosonde Data at a Tropical Location, Int. J. Geosci., 3, 44-49.

Dintelmann, F., and G. Ortgies (1989). Semiempirical model for cloud attenuation prediction, Electron. Lett., 25 (22), 1487-1488.

Dissanyake, A., J. Allnut and F. Haidara (1997). A prediction model that combines rainattenuation and other propagation impairments along earth satellite paths, IEEE Trans. Antennas Propag., 45, 1546-1558.

Durre, I., R.S. Vose and D.B. Wuertz (2006). Overview of the Integrated Global Radiosonde Archive, J. Climate, 19, 53-68.

Geleyn, I.F. (1980). Some diagnostics of the cloud/radiation interaction in ECMWF forecasting model, In: ECMWF Workshop on Radiation and Cloud-Radiation interaction in numerical modelling (Octo- ber 15-17, ECMWF), 133-162.

Gunn, K.L., and T.W. East (1954). The Microwave Properties of Precipitation Particles, Quart. 1. Royal Meteor. Suc., 80, 522-545.

Hahn, C.J., and S.G. Warren (1999). Extended Edited Cloud Reports from Ships and Land Stations over the Globe, 1952-1996. Numerical Data package NDP-026C, Carbon Dioxide Information Analysis Center (CDIAC), Department of Energy, Oak Ridge, Tennessee Documentation.

ITU-R (2009a). Attenuation due to clouds and fog, ITUR Recomm. P.840-4, Geneva, Switzerland.

ITU-R (2009b). Guide to the application of the propagation methods of Radiocommunication Study Group 3, ITU-R Recomm. P.1144-5, Geneva, Switzerland.

ITU-R Study Group 3 (SG 3) (2011). Software for Ionospheric and Tropospheric propagation and radio noise data; http:/ / www.itu.int/oth/R0A04000065/en. 

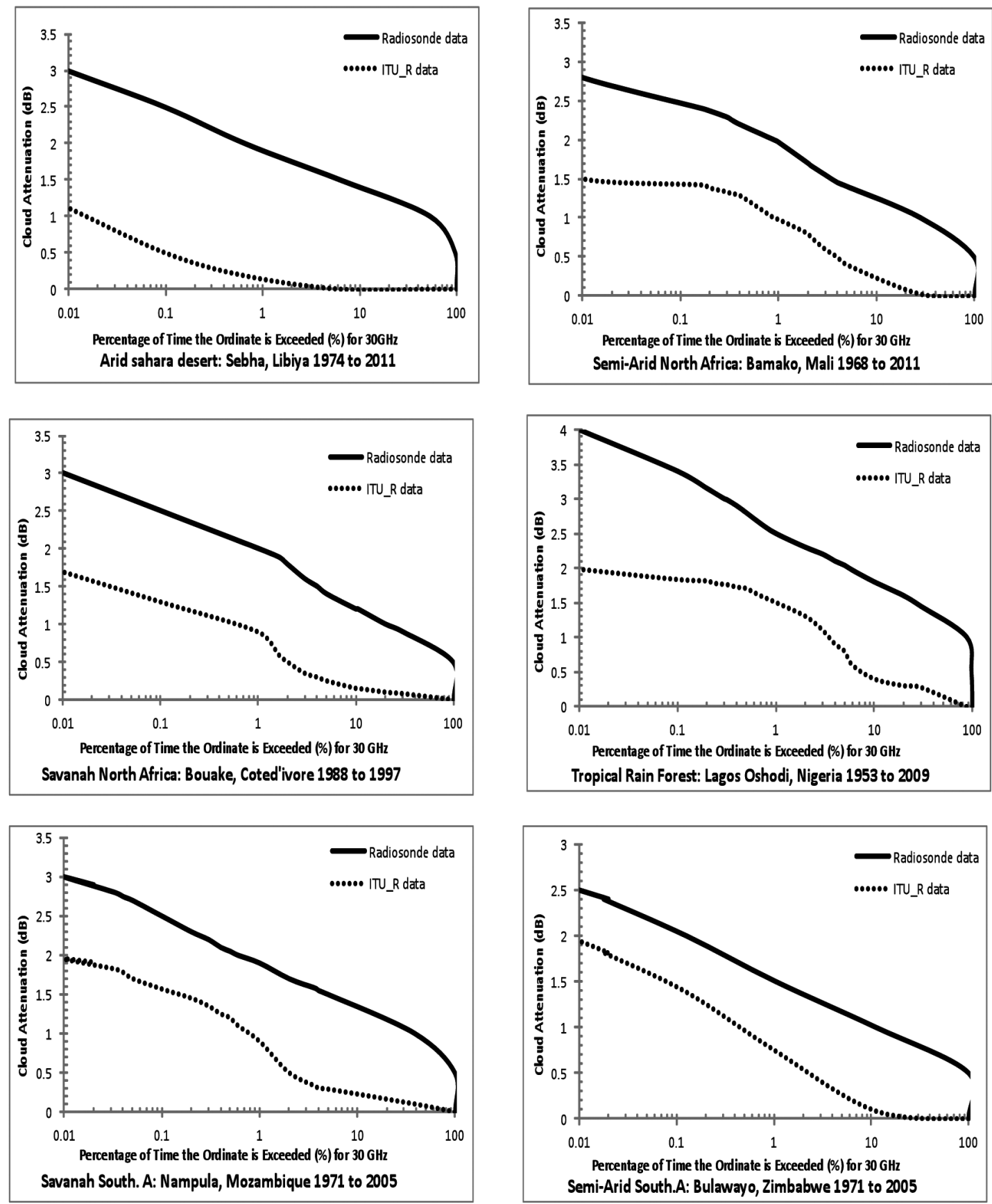

Figure 10. Cumulative distribution of cloud attenuation at $30 \mathrm{GHz}$ obtained from radiosonde measurements. Also shown is the data obtained from the ITU-R model for the six major climatic zones of Africa.

Liebe, H.J. (1989). MPM, An atmospheric millimeter wave propagation model, Int. J. Infrared Millimeter Waves, 10 (6), 631-650.

Mandeep, J.S., and S.I.S. Hassan (2008). Cloud attenuation in millimeter wave and microwave frequencies for satellite applications over equatorial climate, Int. J. Infrared Millimeter Waves, 29, 201-206.

Mattioli, E., P. Basili, S. Bonafoni, P. Ciotti and E.R. Westwater (2009). Analysis and improvements of cloud models for propagation studies, Radio Science, 44, RS2005; doi:10.1029/2008RS003876.

Omotosho,T.V, and E.B. Babatunde (2010). Study of Cloud Impact on Fixed Satellite Communication Link at $\mathrm{Ku}, \mathrm{Ka}$ and $\mathrm{V}$ Bands in Nigeria, Australian Journal of Basic and Applied Sciences, 4 (8), 3287-3298.

Omotosho, T.V., J.S.Mandeep and A. Mardina (2011). Cloud-Cover Statistics and Cloud Attenuation at Kaand V-Bands for Satellite Systems Design in Tropical Wet Climate, IEEE Antennas And Wireless Propagation Letters, 10, 1194-1196.

Salonen, E., and W. Uppala (1991). New prediction method of cloud attenuation, Electron. Lett., 27 (12), 1106-1108.

Sarkar, S.K., I. Ahmad, J. Das and A.K. De (2005). Cloud height, cloud temperature and cloud attenuation in microwave and millimeter wave frequency bands 

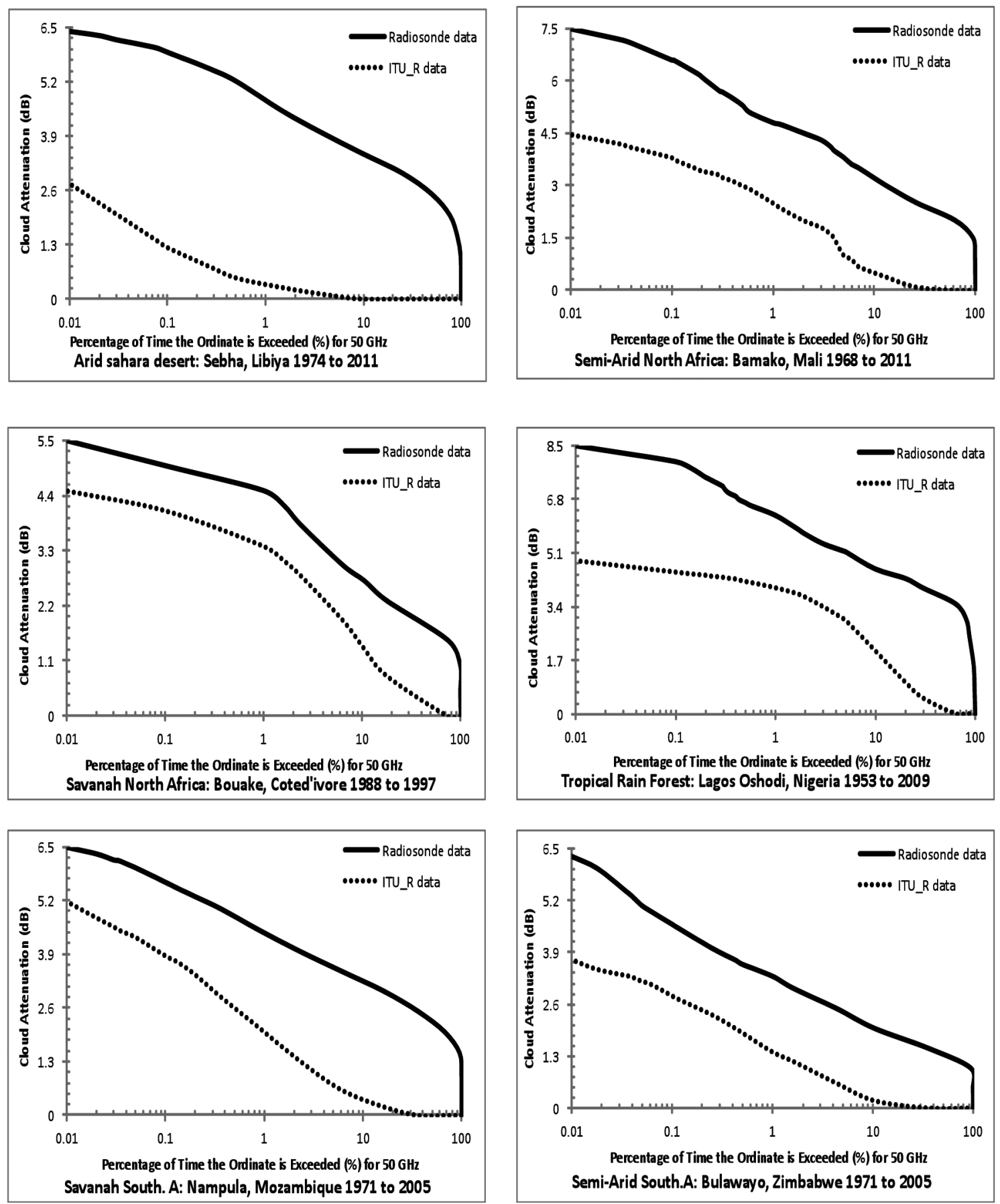

Figure 11. Cumulative distribution of cloud attenuation at $50 \mathrm{GHz}$ obtained from radiosonde measurements. Also shown is the data obtained from the ITU-R model for the six major climatic zones of Africa.

over Indian tropical east cost, Int. J. Infrared Millimeter Waves, 26, 329-340.

Slobin, S.D. (1982). Microwave noise temperature and attenuation of clouds: Statistics of these effects at various sites in the United States, Alaska and Hawaii, Radio Sci., 17, 1443-1454.

Staelin. D.H. (1966). Measurements and Interpretation of the Microwave Spectrum of the Terrestrial Atmosphere near I-Centimeter Wavelength, J. Geophys. Res., 71 (12), 2875-2881.

Warren, S.G., and C.J. Hahn (2003). CLOUDS / Climatology, Encyclopedia of Atmospheric Sciences,
476-483.

Wrench, C.L., P.G. Davies and J. Ramsden (1999). Global prediction of slant path attenuation on Earth space links at EHF, Int. J. Satell. Commun., 17, 177-186.

\footnotetext{
${ }^{\star}$ Corresponding author: Temidayo Victor Omotosho, Covenant University, Department of Physics, Ota, Ogun State, Nigeria; email: temidayo.omotosho@yahoo.com.
}

(C) 2013 by the Istituto Nazionale di Geofisica e Vulcanologia. All rights reserved. 